\title{
Relation between oesophageal acid exposure and healing of oesophagitis with omeprazole in patients with severe reflux oesophagitis
}

\author{
R H Holloway, J Dent, F Narielvala, A M Mackinnon
}

\begin{abstract}
Background/aims-Reducing oesophageal acid exposure by suppressing acid secretion with omeprazole is highly effective in healing reflux oesophagitis. Some patients with severe oesophagitis, fail to heal and whether this results from inadequate acid suppression or other factors is unclear. The aim of this study, was to investigate the relation between oesophageal acid exposure and healing in patients with severe reflux oesophagitis treated with omeprazole.

Methods-Sixty one patients with grade 3 or 4 ulcerative oesophagitis were treated for eight weeks with omeprazole $20 \mathrm{mg}$ every morning. Those patients unhealed at eight weeks were treated with $40 \mathrm{mg}$ every morning for a further eight weeks. Endoscopy and 24 hour oesophageal pH monitoring were performed before treatment and at the end of each treatment phase while receiving treatment.

Results-Thirty per cent of patients failed to heal with the $20 \mathrm{mg}$ dose. Unhealed patients had greater total 24 hour oesophageal acid exposure before treatment, and while receiving treatment also had greater acid exposure and a smaller reduction in acid exposure than did patients who healed. Forty seven per cent of the unhealed patients also failed to heal with the $40 \mathrm{mg}$ dose. These patients had similar levels of acid exposure before treatment to those who healed, but had greater acid exposure while receiving treatment, particularly at night when supine.

Conclusions-Patients with severe ulcerative oesophagitis who are refractory to omeprazole have greater oesophageal acid exposure while receiving treatment than responding patients. This is due to a reduced responsiveness to acid suppression, and is likely to be an important factor underlying the failure of the oesophagitis to heal.

(Gut 1996; 38: 649-654)
\end{abstract}

Keywords: gastro-oesophageal reflux, $\mathrm{pH}$ monitoring, gastric acid secretion, oesophagus.
The duration of oesophageal acid exposure is the most important factor determining the severity of reflux symptoms ${ }^{1}$ and the degree of oesophagitis ${ }^{23}$. Sustained high level acid suppression with the potent acid pump inhibitor, omeprazole, has proved an extremely effective treatment for reflux oesophagitis. Complete healing has been reported in $70 \%$ to $90 \%$ of patients $^{4-10}$ even in patients who were refractory to $\mathrm{H}_{2}$ receptor antagonists ${ }^{11-14}$. Healing rates, however, in the most severely affected patients with endoscopic grades 3 and 4 are substantially less, only $58 \%$, with doses up to $40 \mathrm{mg}$ per day ${ }^{6}$. The reasons for this failure are not clear. A direct relation exists between healing rate and the degree of acid suppression over 24 hours $^{15}$, and inadequate acid suppression appears to be an important factor underlying the failure to heal with $\mathrm{H}_{2}$ receptor antagonists. ${ }^{516} \mathrm{~A}$ recent study ${ }^{17}$ in patients with severe reflux oesophagitis that was refractory to omeprazole showed that such patients had persistent pathological reflux, particularly at night. However, the relation between oesophageal acid exposure and healing of oesophagitis with omeprazole has not been formally studied in a prospective manner. The aim of this study, therefore, was to investigate the relation between oesophageal acid exposure and healing of oesophagitis with omeprazole in patients with severe oesophagitis.

\section{Methods}

Patients

Sixty one outpatients (49 M, $12 \mathrm{~F}$ age range 23-86 years, mean 63) with severe reflux oesophagitis, endoscopic grade 3 or $4^{6}$ were recruited at three Adelaide university teaching hospitals: Royal Adelaide Hospital (22 patients), Repatriation General Hospital (21 patients), and Flinders Medical Centre (17 patients). Patients were excluded if aged under 18 years. Other reasons for exclusion were previous oesophageal gastric or duodenal surgery except for simple closure of a perforation or dilatation, presence of strictures (other than mild) requiring dilatation, oesophagitis due to systemic disease, infection, intubation or other mechanical trauma, caustic or other burns, irradiation or physical deformity, concurrent gastric or duodenal ulcer or oesophageal 
varices, ongoing upper gastrointestinal haemorrhage, other serious illness (cardiac, renal or hepatic disease, or evidence of malignancy), treatment with an investigational drug within four weeks of the initial endoscopy or use of any antisecretory or prokinetic agent after the initial endoscopy, and alcoholism, drug misuse or other conditions considered to interfere with patient compliance. No pregnant or lactating women were included in the study. Use of analgesics and non-steroidal antiinflammatory agents was noted but patients using them were not excluded. Mild strictures were dilated before entry at the discretion of the endoscopist. The study was approved by the human ethics committees at each of the three participating hospitals and each patient gave their written informed consent.

\section{Study design}

The study was of open design. Ambulatory oesophageal $\mathrm{pH}$ monitoring was performed within one week of the initial endoscopy. A minimum washout period of two days for patients treated with $\mathrm{H}_{2}$ antagonists or five days for patients treated with omeprazole was allowed before the $\mathrm{pH}$ monitoring. Patients were then treated with omeprazole $20 \mathrm{mg}$ daily for eight weeks. Endoscopy and $\mathrm{pH}$ monitoring were repeated during the last week while receiving treatment. Patients whose oesophagitis had healed as evidenced by complete resolution of all macroscopic erosions or ulceration left the study at this point. Those patients with persistent erosions or ulceration were treated with omeprazole $40 \mathrm{mg}$ daily for eight weeks and endoscopy and $\mathrm{pH}$ monitoring repeated during the last week as before.

\section{Endoscopy}

Upper gastrointestinal endoscopy (Olympus GIF XQ10 or Pentax FG34JH) was performed by an experienced observer not more than 10 days before starting treatment. When the endoscopy was performed at the end of a treatment phase, the endoscopist was blinded to the results of the $\mathrm{pH}$ monitoring. The severity and extent of macroscopic oesophageal ulceration or erosion was scored as follows ${ }^{6}$ : grade 0 , no mucosal abnormalities; grade 1 , no macroscopic erosions but erythema, hyperaemia or mucosal friability; grade 2, superficial erosions involving $<10 \%$ of the mucosal surface of the distal $5 \mathrm{~cm}$ of oesophageal squamous mucosa; grade 3 , superficial erosions or ulceration involving $10 \%-50 \%$ of the mucosal surface of the distal $5 \mathrm{~cm}$ of the oesophageal squamous mucosa; grade 4, deep peptic ulceration anywhere in the oesophagus or confluent erosion of $>50 \%$ of the mucosal surface of the distal 5 $\mathrm{cm}$ of the oesophageal squamous mucosa. Only patients with unequivocal severe erosive peptic oesophagitis of grade 3 or 4 were entered into the study. Patients with reflux disease characterised by columnar metaplasia or benign stricture without macroscopic mucosal erosion were not entered.

\section{Oesophageal pH monitoring}

Twenty four hour ambulatory oesophageal $\mathrm{pH}$ monitoring was performed using an antimony $\mathrm{pH}$ electrode (Synectics) positioned $5 \mathrm{~cm}$ above the manometrically determined lower oesophageal sphincter and connected to a portable digital recorder (Synectics Digitrapper Mark II 6100). Patients were requested to avoid drinking coffee, cordials, and fruit juices during the recording period. Omeprazole treatment was continued but patients were not allowed to take any antacid.

\section{Clinical and laboratory assessment}

Symptoms were assessed by interview at entry and at four weekly intervals during the study. Heartburn, (day and night scored separately), regurgitation and dysphagia were graded as: 0 - none, 1 - mild, not interfering with usual activity; 2 - moderate, interfering with usual activity; and 3 - severe, incapacitating and preventing usual activity. Patients were specifically questioned about the occurrence of adverse events or symptoms. Compliance, assessed at each visit by capsule counts, was judged to be adequate only if at least $75 \%$ of the capsules had been consumed. Blood samples were taken for haematological and biochemical testing.

\section{Data analysis}

The $\mathrm{pH}$ data were analysed by computer (Synectics, Esophogram) for the duration $\mathrm{pH}<4$ and the number of reflux episodes. Acid clearance time was calculated by dividing the duration $\mathrm{pH}<4$ by the number of reflux episodes. Values were determined separately for the total 24 hours, and upright, supine, and three hour postprandial periods. Data for healed and unhealed patients were compared using the Mann-Whitney $U$ test and are expressed in the text as median (interquartile range).

\section{Results}

\section{Pre-treatment}

Sixty patients entered the study of which 59 received medication; one patient withdrew

TABLE I Clinical and endoscopic data at entry into the study

\begin{tabular}{lll}
\hline & $\begin{array}{l}\text { Omeprazole } \\
(20 \mathrm{mg})\end{array}$ & $\begin{array}{l}\text { Omeprazole } \\
(40 \mathrm{mg})\end{array}$ \\
\hline Number entered & 60 & 17 \\
Male:female & $48: 12$ & $16: 1$ \\
Mean age (range) (y) & $63(23-86)$ & $65(23-84)$ \\
Symptom duration & & \\
<1 Year & 6 & 2 \\
$\quad$ 1-5 Years & 16 & 6 \\
>5 Years & 37 & 9 \\
Cigarette smokers & 9 & 2 \\
Recent NSAID use & 9 & 1 \\
Recent aspirin use & 15 & 4 \\
Recent H2 receptor antagonists & 26 & 10 \\
Oesophagitis at entry & 44 & 12 \\
$\quad$ Grade 3 & 15 & 5 \\
Grade 4 & 39 & 8 \\
Columnar mucosa & 5 & 3 \\
Deep ulcer & 6 & 2 \\
Stricture & & \\
\hline
\end{tabular}

NSAID, non-steroidal anti-inflammatory drug. 


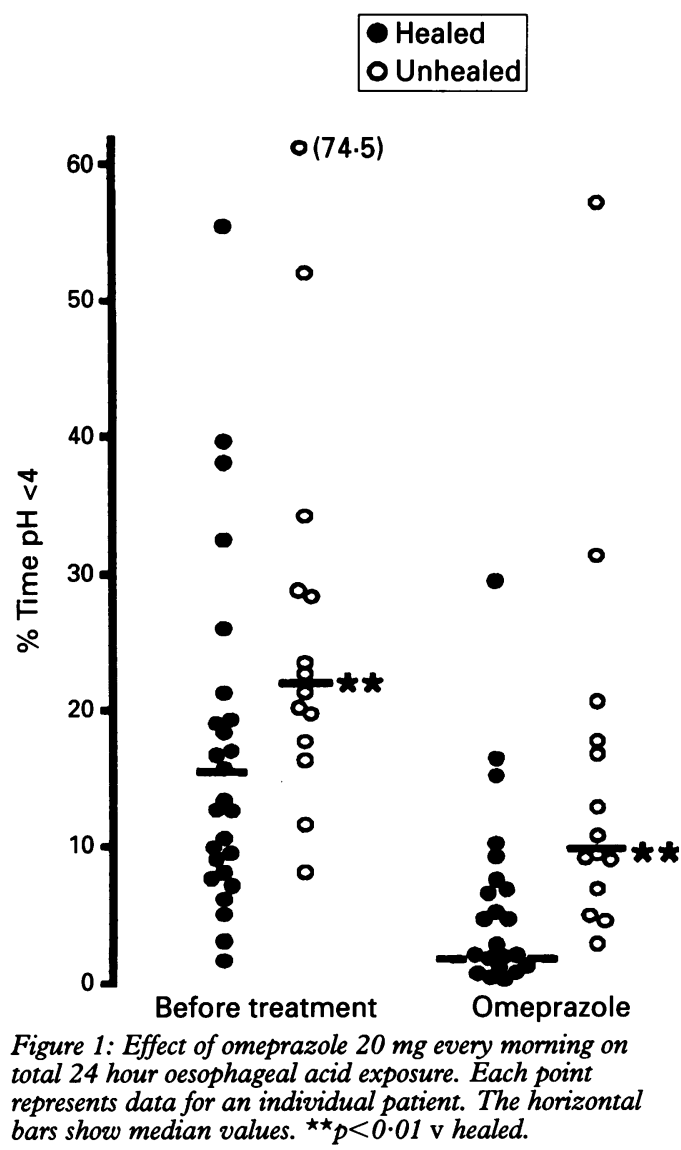

before receiving medication. Four patients were withdrawn from the study. Reasons for withdrawal were: nausea that occurred within 24 hours of starting omeprazole (one patient), failure to comply (one patient), loss to follow up (three patients) thus leaving 55 patients available for analysis. Table I summarises the demographic, clinical and endoscopic data on entry into the trial.

Pre-treatment total 24 hour oesophageal acid exposure in the patients who did not heal with omeprazole $20 \mathrm{mg}$ was significantly greater than that in the patients who healed (Fig 1). Ten of $17(59 \%)$ unhealed patients had received $\mathrm{H}_{2}$ antagonists before the study compared with 16 of $38(42 \%)$ patients who healed. Total 24 hour acid exposure in the unhealed patients who had taken $\mathrm{H}_{2}$ antagonists $(28.8 \%$, $22 \cdot 6-34 \cdot 2 \%$ ) was significantly greater than in those who had not taken $\mathrm{H}_{2}$ antagonists $(17 \cdot 0 \%, 11 \cdot 1-19 \cdot 8 \%, p<0.03)$. Previous use of $\mathrm{H}_{2}$ antagonists, however, did not affect acid exposure in the patients who healed $(19 \cdot 8 \%$, $14 \cdot 6-19 \cdot 8 \%$ v $20 \cdot 2 \%, 16 \cdot 5-20 \cdot 2 \%$ ).

Values for pre-treatment upright, supine, and postprandial acid exposure, however, were similar in the two groups (Table II). Pre-treatment acid clearance times were also similar in the two groups (healed: $1 \cdot 7 \mathrm{~min}, 0.6-3.0 \mathrm{~min}$; unhealed: $3.5 \mathrm{~min}, 2 \cdot 6-5 \cdot 1 \mathrm{~min}$ ).

For patients who remained unhealed on 20 $\mathrm{mg}$ omeprazole and subsequently received the $40 \mathrm{mg}$ dose, pre-treatment total, upright, supine, and postprandial oesophageal acid exposures were similar in those who eventually healed and those who remained unhealed (Table III, Fig 2). Oesophageal acid clearance time before treatment was also similar in the healed patients $(3.1 \mathrm{~min}, 2 \cdot 6-6 \cdot 2 \mathrm{~min})$ to that in the unhealed patients $(3.9 \mathrm{~min}, 3.5-5.9$ $\mathrm{min}$ ).

Phase 1: omeprazole $20 \mathrm{mg}$

Seventeen patients failed to heal their oesophagitis after eight weeks' treatment with omeprazole $20 \mathrm{mg}$ every morning. Total 24 hour oesophageal acid exposure while receiving treatment was significantly greater in those patients who failed to heal than in those who healed (Fig 1), and significantly fewer unhealed patients fell within the normal range of $<5 \%$ (4 of 17 patients $v 27$ of 38 patients, $\mathrm{p}<0.005$ ). The mean percentage fall in total acid exposure with treatment in the unhealed patients $(45 \%)$ was significantly less than that in the healed patients $(82 \%), p<0.02)$. Unhealed patients also had greater levels of upright, supine, and postprandial reflux during treatment than did those who healed (Table II).

Most patients (47 of 55) were rendered symptom free after eight weeks of treatment. The prevalence of complete symptom relief in the patients who did not heal (15 of 17 patients) was similar to that in those who healed ( 32 of 38 patients). The use of histamine $\mathrm{H}_{2}$ receptor antagonists before entry into the trial (healed $-42 \%$, unhealed $-58 \%$ ), nonsteroidal anti-inflammatory agents (healed $45 \%$, unhealed $-29 \%$ ), and smoking (healed four of 38, unhealed - one of 16) were not statistically different in the two groups.

\section{Phase 2: omeprazole $40 \mathrm{mg}$}

Sixteen of 17 patients who failed to heal with omeprazole $20 \mathrm{mg}$ received eight weeks treatment with omeprazole $40 \mathrm{mg}$ every morning; one patient withdrew at week 8 for social reasons. Two other patients refused to undergo further $\mathrm{pH}$ monitoring leaving 14 patients available for analysis. Eight of 15 patients who underwent endoscopy healed their oesophagitis with the larger dose. All patients who healed

TABLE II Oesophageal acid exposure with omeprazole 20 mg every morning

\begin{tabular}{|c|c|c|c|c|c|c|c|c|}
\hline \multirow[b]{3}{*}{$\begin{array}{l}\text { Patient } \\
\text { group }\end{array}$} & \multicolumn{8}{|c|}{ Oesophageal acid exposure } \\
\hline & \multicolumn{4}{|l|}{ Pre-treatment } & \multicolumn{4}{|c|}{ Omeprazole $20 \mathrm{mg}$} \\
\hline & $\begin{array}{l}\text { Total } \\
(\%)\end{array}$ & $\begin{array}{l}\text { Upright } \\
(\%)\end{array}$ & $\begin{array}{l}\text { Supine } \\
(\%)\end{array}$ & $\begin{array}{l}\text { Postprandial } \\
\text { (\%) }\end{array}$ & $\begin{array}{l}\text { Total } \\
(\%)\end{array}$ & $\begin{array}{l}\text { Upright } \\
(\%)\end{array}$ & $\begin{array}{l}\text { Supine } \\
(\%)\end{array}$ & $\begin{array}{l}\text { Postprandial } \\
(\%)\end{array}$ \\
\hline $\begin{array}{l}\text { Healed } \\
\text { Unhealed }\end{array}$ & $\begin{array}{l}16 \cdot 0 \\
(8 \cdot 4-20 \cdot 3) \\
21 \cdot 3^{\star} \\
(16 \cdot 2-28 \cdot 8)\end{array}$ & $\begin{array}{l}14 \cdot 5 \\
(9 \cdot 3-21 \cdot 9) \\
23 \cdot 3 \\
(10 \cdot 6-26 \cdot 3)\end{array}$ & $\begin{array}{l}13 \cdot 7 \\
(5 \cdot 5-22 \cdot 2) \\
15 \cdot 3 \\
(8 \cdot 4-43 \cdot 9)\end{array}$ & $\begin{array}{l}18 \cdot 9 \\
(13 \cdot 7-28 \cdot 3) \\
27 \cdot 7 \\
(14 \cdot 0-34 \cdot 4)\end{array}$ & $\begin{array}{l}1 \cdot 8 \\
(0 \cdot 2-6 \cdot 1) \\
9 \cdot 1 \dagger \\
(6 \cdot 6-17 \cdot 5)\end{array}$ & $\begin{array}{l}1 \cdot 3 \\
(0 \cdot 4-3 \cdot 4) \\
7 \cdot 2^{\star} \\
(1 \cdot 4-14 \cdot 0)\end{array}$ & $\begin{array}{l}0 \cdot 6 \\
(0-7 \cdot 0) \\
17 \cdot 1^{\star} \\
(0 \cdot 5-23 \cdot 8)\end{array}$ & $\begin{array}{l}0 \cdot 2 \\
(0-2 \cdot 1) \\
1 \cdot 7^{\star} \\
(0 \cdot 5-12 \cdot 4)\end{array}$ \\
\hline
\end{tabular}

Median (interquartile range), ${ }^{\star} \mathrm{p}<0.03, \mathrm{tp}<0 \cdot 01, v$ healed. 
TABLE III Oesophageal acid exposure with omeprazole $40 \mathrm{mg}$ every morning

\begin{tabular}{|c|c|c|c|c|c|c|c|c|c|c|c|c|}
\hline \multirow[b]{3}{*}{$\begin{array}{l}\text { Patient } \\
\text { group }\end{array}$} & \multicolumn{12}{|c|}{ Oesophageal acid exposure } \\
\hline & \multicolumn{4}{|l|}{ Pre-treatment } & \multicolumn{4}{|c|}{ Omeprazole $(20 \mathrm{mg})$} & \multicolumn{4}{|c|}{ Omeprazole (40 mg) } \\
\hline & $\begin{array}{l}\text { Total } \\
(\%)\end{array}$ & $\begin{array}{l}\text { Upright } \\
(\%)\end{array}$ & $\begin{array}{l}\text { Supine } \\
(\%)\end{array}$ & $\begin{array}{l}\text { Postprandial } \\
\text { (\%) }\end{array}$ & $\begin{array}{l}\text { Total } \\
\text { (\%) }\end{array}$ & $\begin{array}{l}\text { Upright } \\
(\%)\end{array}$ & $\begin{array}{l}\text { Supine } \\
(\%)\end{array}$ & $\begin{array}{l}\text { Postprandial } \\
(\%)\end{array}$ & $\begin{array}{l}\text { Total } \\
(\%)\end{array}$ & $\begin{array}{l}\text { Upright } \\
(\%)\end{array}$ & $\begin{array}{l}\text { Supine } \\
(\%)\end{array}$ & $\begin{array}{l}\text { Postprandial } \\
\text { (\%) }\end{array}$ \\
\hline Healed & $\begin{array}{l}20 \cdot 8 \\
(19 \cdot 2-24 \cdot 8)\end{array}$ & $\begin{array}{l}25 \cdot 3 \\
(19 \cdot 2-26 \cdot 8)\end{array}$ & $\begin{array}{l}13 \cdot 7 \\
(6 \cdot 3-34 \cdot 8)\end{array}$ & $\begin{array}{l}29 \cdot 8 \\
(24 \cdot 7-34 \cdot 6)\end{array}$ & $\begin{array}{l}7 \cdot 7 \\
(4 \cdot 6-11 \cdot 0)\end{array}$ & $\begin{array}{l}7 \cdot 4 \\
(3 \cdot 0-15 \cdot 9)\end{array}$ & $\begin{array}{l}3 \cdot 2 \\
(0 \cdot 3-10 \cdot 7)\end{array}$ & $\begin{array}{l}4 \cdot 2 \\
(0 \cdot 7-14 \cdot 2)\end{array}$ & $\begin{array}{l}1 \cdot 3 \\
(0 \cdot 1-3 \cdot 4)\end{array}$ & $\begin{array}{l}0.3 \\
(0 \cdot 1-0 \cdot 8)\end{array}$ & $\begin{array}{l}2 \cdot 0 \\
(0 \cdot 1-4 \cdot 9)\end{array}$ & $\begin{array}{l}0.2 \\
(0-0 \cdot 4)\end{array}$ \\
\hline Unhealed & $\begin{array}{l}28 \cdot 4 \\
(19 \cdot 4-34 \cdot 2)\end{array}$ & $\begin{array}{l}20 \cdot 2 \\
(10 \cdot 9-25 \cdot 3)\end{array}$ & $\begin{array}{l}43 \cdot 9 \\
(22 \cdot 2-50 \cdot 3)\end{array}$ & $\begin{array}{l}26 \cdot 3 \\
(18 \cdot 8-31 \cdot 9)\end{array}$ & $\begin{array}{l}17 \cdot 5 \\
(11 \cdot 6-19 \cdot 7)\end{array}$ & $\begin{array}{l}2 \cdot 3 \\
(1 \cdot 5-12 \cdot 1)\end{array}$ & $\begin{array}{l}24 \cdot 9 \dagger \\
(22 \cdot 3-47 \cdot 6)\end{array}$ & $\begin{array}{l}1 \cdot 7 \\
(0 \cdot 6-11 \cdot 6)\end{array}$ & $\begin{array}{l}18 \cdot 1 \dagger \\
(15 \cdot 9-19 \cdot 9)\end{array}$ & $\begin{array}{l}9 \cdot 1^{\star} \\
(4 \cdot 8-10 \cdot 2)\end{array}$ & $\begin{array}{l}33.0 \dagger \\
(31 \cdot 8-39 \cdot 8)\end{array}$ & $\begin{array}{l}7 \cdot 4 \\
(1 \cdot 7-16 \cdot 1)\end{array}$ \\
\hline
\end{tabular}

Median (interquartile range), ${ }^{\star} \mathrm{p}<0.05,+\mathrm{p}<0.005 v$ healed.

and four of six unhealed patients were rendered asymptomatic; two unhealed patients had residual mild heartburn (grade 1).

During treatment total oesophageal acid exposure was significantly greater in those patients who failed to heal than in those who healed (Fig 2), and all unhealed patients had acid exposures above $5 \%$ (range $10 \cdot 3-21 \cdot 8 \%$ ) compared with only one of eight healed patients. Upright acid exposure was similar in the healed and unhealed patients while receiving $20 \mathrm{mg}$ omeprazole but was significantly greater in the unhealed patients with the $40 \mathrm{mg}$ dose (Table III). Supine acid exposure, however, was significantly greater in the unhealed patients during treatment with both the $20 \mathrm{mg}$ dose and $40 \mathrm{mg}$ dose. Postprandial acid exposure was similar in the healed and unhealed patients with both the $20 \mathrm{mg}$ and $40 \mathrm{mg}$ doses.

\section{Discussion}

In this study we evaluated prospectively the relation between oesophageal acid exposure and healing of oesophagitis in patients with severe reflux oesophagitis treated with omeprazole. Our data show that failure of oesophagitis to heal is associated with a higher level of oesophageal acid exposure before treatment, and higher levels of acid exposure while receiving omeprazole because of a smaller reduction in acid exposure, particularly at night. These findings are consistent with the hypothesis that failure of oesophagitis to heal with omeprazole is due to inadequate acid suppression.

Severity of oesophagitis as judged by endoscopy before treatment is the most important
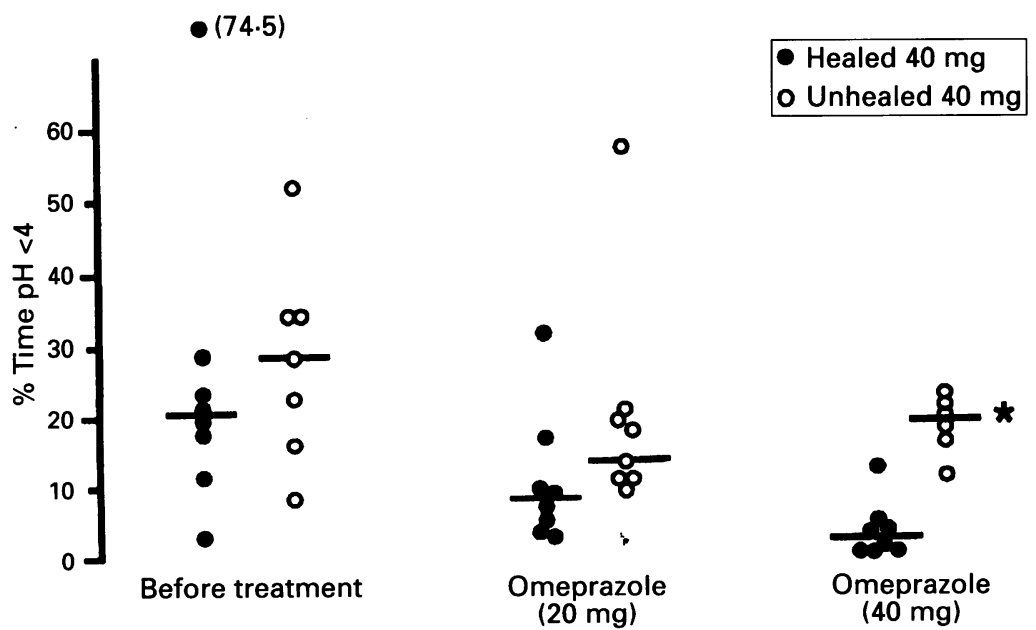

Figure 2: Effect of omeprazole $40 \mathrm{mg}$ every morning on total 24 hour oesophageal acid exposure. Each point represents data for an individual patient. The horizontal bars show median values. ${ }^{\star} p<0.005 \mathrm{v}$ healed. factor determining the response to treatment with acid suppressant drugs.4671819 We selected patients with severe reflux oesophagitis as we have shown previously that such patients are more refractory to omeprazole than patients with lesser degrees of oesophagitis. ${ }^{6}$ Most of the patients had proved refractory to $\mathrm{H}_{2}$ receptor antagonists. The healing rate with the $20 \mathrm{mg}$ dose in this study $(69 \%)$ is comparable to that seen previously, ${ }^{6}$ and illustrates the difficulty in treating patients with severe oesophagitis even with potent acid suppressants. In contrast with earlier studies, however, which reported similar healing rates with $20 \mathrm{mg}$ and $40 \mathrm{mg}$ doses, ${ }^{68}$ doubling the dose of omeprazole from $20 \mathrm{mg}$ to $40 \mathrm{mg}$ in this study was associated with healing of the oesophagitis in an additional $15 \%$ of the patients. This increase in healing rate may have been a result of a longer duration of treatment in the patients who received the $40 \mathrm{mg}$ dose as these patients had already received eight weeks' treatment with the $20 \mathrm{mg}$ dose; in the previous studies, patients received only eight weeks' treatment overall.

The important finding from this study was that failure of oesophagitis to heal was associated with higher levels of acid exposure on treatment. There are two main explanations for this finding. Firstly, patients that remained unhealed on the $20 \mathrm{mg}$ dose had higher levels of acid exposure before treatment. Previous findings on the relation between pre-treatment oesophageal acid exposure and response to acid suppression have been conflicting. Some studies have shown no relation. ${ }^{162021}$ A direct relation has been reported, however, in patients refractory to $\mathrm{H}_{2}$ antagonists $22{ }^{23}$ and may be a consequence of more defective gastro-oesophageal competence or more severely impaired oesophageal acid clearance or both in the refractory patients. It has also been suggested that higher pre-treatment acid exposure is related to gastric acid hypersecretion. $^{23}$

In this study, however, the higher pre-treatment acid exposure may have been related to prior use of $\mathrm{H}_{2}$ antagonists. Cessation of these drugs is associated with rebound gastric hypersecretion. ${ }^{24}$ Pre-treatment acid exposure was higher only in patients who did not heal and who had been taking $\mathrm{H}_{2}$ antagonists before entering the study; acid exposure was similar in healed and unhealed patents who had not taken $\mathrm{H}_{2}$ antagonists. Interestingly, previous use of $\mathbf{H}_{2}$ antagonists did not affect pre-treatment acid exposure in patients who healed with the $20 \mathrm{mg}$ omeprazole dose suggesting 
that patients who did not heal may have different patterns of acid secretion. Despite the confounding factor of $\mathrm{H}_{2}$ antagonists, however, differences in reflux patterns cannot account for the failure of patients to respond to the higher dose of omeprazole as the pre-treatment oesophageal acid exposure levels in these patients were no different from those in the patients who healed with this dose.

Secondly, and more importantly, our data suggest that failure of oesophagitis to heal is associated with lower degrees of acid suppression. Patients who did not heal with the $20 \mathrm{mg}$ dose not only had higher levels of acid exposure while receiving treatment but also had a significantly smaller reduction in acid exposure. Additionally, patients that remained unhealed with the $40 \mathrm{mg}$ dose had substantially higher levels of acid exposure on treatment despite similar pretreatment levels of acid exposure to those in patients who healed. Although we did not measure gastric acid secretion, these findings are best explained by a relative refractoriness to acid suppression with omeprazole in a subgroup of patients with severe oesophagitis. The reasons for this are not clear. Possibilities include: gastric hypersecretion, a decreased response of the parietal cell, perhaps related to increased drive for acid secretion, poor absorption, and changed pharmacokinetics with increased metabolic rate or elimination. ${ }^{25}$ Whether or not reflux disease in general ${ }^{26-28}$ or that refractory to acid suppressant treatment ${ }^{182329}$ is associated with acid hypersecretion is controversial. Patients with duodenal ulcer exhibit substantial variability in acid suppression with low (10 mg) doses of omeprazole, which becomes less noticeable with higher doses. ${ }^{30}$

While oesophageal acid exposure was higher overall in unhealed patients, the important component was -a higher level of supine and therefore nocturnal reflux. Indeed, the $40 \mathrm{mg}$ dose had virtually no impact on supine reflux in the patients who failed to heal. These findings confirm previous reports of persistently increased supine and nocturnal oesophageal acid exposure in patients with reflux oesophagitis resistant to omeprazole. ${ }^{517}$ In part this is probably a result of refractoriness of nocturnal acid secretion. Omeprazole in doses of $20 \mathrm{mg}$ or greater virtually ablates daytime acid secretion, whereas partial breakthrough occurs at night. ${ }^{31-33}$ Whether nocturnal breakthrough is more noticeable in patients with refractory reflux disease, however, awaits specific study. While persistence of nocturnal oesophageal acid exposure could also result from more defective acid clearance, this hypothesis is not supported by our finding that acid clearance times before treatment were similar in healed and unhealed patients for both the $20 \mathrm{mg}$ and $40 \mathrm{mg}$ doses.

Oesophageal acid exposure was not the only determinant of healing. Some patients healed despite continuing high levels of acid exposure, and some patients failed to heal despite reduction of acid exposure to below normal levels. Aspirin use has been implicated as a significant factor in the resistance of oesophagitis treatment. ${ }^{34}$ As with other studies, however, ${ }^{6} 8$ smoking or the use of non-steroidal antiinflammatory drugs including aspirin did not affect the rate of healing. Increased exposure to bile salts has been reported in patients with severe reflux disease. ${ }^{35}$ Whether patients who are refractory to omeprazole have greater oesophageal exposure to these agents, however, remains to be determined.

In summary we have shown that failure of severe oesophagitis to heal with omeprazole is associated with persistence of a high level of oesophageal acid exposure that is most consistent with inadequate suppression of acid secretion. The mechanisms underlying this apparent refractoriness require further investigation. Our findings also underline the need in patients with severe reflux disease to titrate the dose of omeprazole to achieve adequate acid suppression, and that oesophageal $\mathrm{pH}$ monitoring is a useful guide for this approach. The apparent breakthrough of nocturnal acid secretion in refractory patients may be just related to dose. Whether or not night time compared with morning dosing, ${ }^{30}$ or dividing the single $40 \mathrm{mg}$ dose into twice daily $20 \mathrm{mg}$ doses $^{37}$ would achieve better healing awaits further study.

This study was supported by a project grant from the NHMRC. Omeprazole capsules and financial support were provided by Astra Pharmaceuticals Pty Ltd, Australia.

The authors would like to thank their colleagues David The authors would like to thank their colleagues David
Hetzel, Peter Pritchard, and Richard Heddle for their invaluHetzel, Peter Pritchard, and Richard Heddle for their invalu-
able support, Marcus Tippett, Joylene Morcombe, and Wendy Ferguson for performing the $\mathrm{pH}$ monitoring studies and help in enrolling and caring for the patients. They also thank Bronwyn Underwood and Katrina Perkins for their constant logistical support.

1 Joelsson B, Johnsson F. Heartburn - the acid test. Gut 1989; 30: 1523-5.

2 de Caestecker JS, Blackwell JN, Pryde A, Heading RC. Daytime gastro-oesophageal reflux is important in Daytime gastro-oesophageal reflux

3 Robertson D, Alersley JM, Shepherd H, Smith CL. Patterns of acid reflux in complicated oesophagitis. Gut 1987; 28: 1484-8.

4 Havelund T, Laursen LS, Skoubo-Kristensen E, Andersen $\mathrm{BN}$, Pedersen SA, Jensen KB, et al. Omeprazole and ranitidine in treatment of reflux oesophagitis: double blind comparative trial. $B M \mathcal{F}$ 1988; 296: 89-92.

5 Dehn TCB, Sheperd HA, Colin-Jones D, Kettlewell MGW, Carroll NJH. Double blind comparison of omeprazole $(40 \mathrm{mg}$ od) versus cimetidine ( $400 \mathrm{mg} \mathrm{ad})$ in the treatment (40mg od) 作 1990; 31: 509-13.

Hetzel DJ, Dent J, Reed WD, Narielvala FM, Mackinnon $\mathrm{M}$, McCarthy $\mathrm{JH}$, et al. Healing and relapse of severe peptic esophagitis after treatment with omeprazole. Gastroenterology 1988; 95: 903-12.

7 Sandmark S, Carlsson R, Fausa O, Lundell L. Omeprazole or ranitidine in the treatment of reflux esophagitis. Results of a double-blind, randomized, Scandinavian multicenter study. Scand f Gastroenterol 1988; 23: 625-32.

8 Sontag SJ, Hirschowitz BI, Holt S, Robinson MG, Behar J, Berenson MM, et al. Two doses of omeprazole versus placebo in symptomatic erosive esophagitis: the U.S. Multicenter Study. Gastroenterology 1992; 102: 109-18.

9 Vantrappen G, Rutgeerts L, Schurmans P, Coenegrachts $\mathrm{JL}$. Omeprazole $(40 \mathrm{mg}$ ) is superior to ranitidine in shortterm treatment of ulcerative reflux esophagitis. Dig Dis $\mathrm{Sci}$ term treatment of

10 Zeitoun P. Comparison of omeprazole with ranitidine in the treatment of reflux oesophagitis. Scand $\mathcal{f}$ Gastroenterol 1989; 24: 83-7.

11 Bardhan KD, Morris $\mathrm{P}$, Thompson M, Dhande DS, Hinchliffe RF, Jones RB, et al. Omeprazole in the treatment of erosive oesophagitis refractory to high dose cimetidine and ranitidine. Gut 1990; 31: 745-9.

12 Koop H, Hotz J, Pommer G, Klein M, Arnold $R$. Prospective evaluation of omeprazole treatment in reflux oesophagitis refractory to H2-receptor antagonists. Aliment Pharmacol Ther 1990; 4: 593-9.

13 Lundell L, Backman L, Ekstrom P, Enander LH, Fausa O, Lind $\mathrm{T}$, et al. Omeprazole of high-dose ranitidine in the treatment of patients with reflux oesophagitis not treatment of patients with reflux oesophagitis not nists. Aliment Pharmacol Ther 1990; 4: 145-55. 
14 Marciano-D'Amore DA, Paterson WG, Da-Costa LR, Beck IT. Omeprazole in $\mathrm{H} 2$ receptor antagonist-resistant reflux esophagitis. F Clin Gastroenterol 1990; 12: 616-20.

15 Bell N, Hunt R. Role of gastric acid suppression in the treatment of gastro-oesophageal reflux disease. Gut 1992; 33: 118-24.

16 Robertson D, Aldersley M, Shepherd H, Lloyd R, Smith R. $\mathrm{H} 2$ Antagonists in the treatment of reflux oesophagitis: can physiological studies predict the response? Gut 1987; 28: $946-9$.

17 Klinkenberg-Knol EC, Meuwissen SGM. Combined gastric and esophageal 24-hour $\mathrm{pH}$ monitoring and esophageal manometry in patients with reflux disease resistant to treatment with omeprazole. Aliment Pharmacol Ther 1990; 4: 485-95.

18 Hirschowitz BI. Acid and pepsin secretion in patients with esophagitis refractory to treatment with $\mathrm{H} 2$ antagonists. Scand $\mathcal{F}$ Gastroenterol 1992; 27: 449-52.

19 Tytgat GN, Nicolai JJ, Reman FC. Efficacy of different doses of cimetidine in the treatment of reflux esophagitis. A review of three large, double-blind, controlled trials. Gastroenterology 1990; 99: 629-34.

20 Lieberman DA. 24-hour esophageal pH monitoring before and after medical therapy for reflux esophagitis. Dig Dis $166-71$.

21 Olden K, Triadafilopoulos G. Failure of initial 24-hour esophageal $\mathrm{pH}$ monitoring to predict refractoriness and intractability in reflux esophagitis. Am $\mathcal{f}$ Gastroenterol 1991; 86: 1142-6.

22 Bianchi-Porro G, Pace F, Sangaletti O. Pattern of acid reflux in patients with reflux esophagitis 'resistant' to $\mathrm{H} 2$-receptor antagonists. Scand 7 Gastroenterol 1990; 25: 810-4.

23 Collen MJ, Lewis JH, Benjamin SB. Gastric acid hypersecretion in refractory gastroesophageal reflux disease. secretion in refractory gastroesoph

24 Frislid K, Aadland E, Berstad A. Augmented postprandial gastric secretion due to exposure to ranitidine in healthy subjects. Scand 7 Gastroenterol 1986; 21: 119-22.

25 Van de Mierop F, Flockhart D, Gallagher J, Maher K, Soukhova N, Gupta PK, et al. Omeprazole metabolism in refractory GERD: pharmacokinetics and pharmacodynamics [Abstract]. Gastroenterology 1995; 108: A249.

26 Hirschowitz BI. A critical analysis, with appropriate esophagitis. Gastroenterology 1991; 101: 1149-58.

27 Barlow A, DeMeester T, Ball C, Eypasch E. The significance of the gastric secretory state in gastroesophagea reflux disease. Arch Surg 1989; 124: 937-40.

28 Mulholland MW, Reid BJ, Levine DS, Rubin CE. Elevated gastric acid secretion in patients with Barrett's metaplastic epithelium. Dig Dis Sci 1989; 34: 1329-35.

29 Collen MJ, Johnson DA, Sheridan MJ. Basal acid output and gastric acid hypersecretion in gastroesophageal reflux disease. Correlation with ranitidine therapy. Dig Dis Sci 1994; 39: 410-7.

30 Savarino V, Mela GS, Zentilin P, Cutela P, Mele MR, Vigneri $S$, et al. Variability in individual response to various doses of omeprazole. Implications for antiulcer therapy. Dig Dis Sci 1994; 39: 161-8.

31 Sharma BK, Walt RP, Pounder RE, Gomes MDFA, Wood EC, Logan LH. Optimal dose of oral omeprazole for maximal 24-hour decrease of intragastric acidity. Gut 1984; 25: 957-64.

32 Lind $\mathrm{T}$, Cederberg $\mathrm{C}$, Idstrom J-P, Lonroth $\mathrm{H}$, Olbe $\mathrm{L}$ Lundell L. 24-hour intragastric acidity and plasma gastrin during long-term treatment with omeprazole or ranitidine in patients with reflux esophagitis. Scand $\mathcal{f}$ Gastroenterol 1991; 26: 620-6.

33 Lanzon-Miller S, Pounder RE, Hamilton MR, Chronos NAF, Ball S, Mercieca JE, et al. Twenty-four-hour intragastric acididty and plasma gastrin concentration in healthy subjects and patients with duodenal or gastric ulcer, or pernicious anaemia. Aliment Pharmacol Ther 1987; 1: 225-37.

34 Lanas A, Hirschowitz B. Significant role of aspirin use in patients with esophagitis. 7 Clin Gastroenterol 1991; 13 622-7.

35 Gotley D, Morgan A, Cooper M. Bile acid concentrations in the refluxate of patients with reflux oesophagitis. in the refluxate of patients

36 Chiverton SG, Howden CW, Burget DW. Omeprazole (20mg) daily given in the morning or evening: a comparison of effects on gastric acidity, plasma gastrin and omeprazole concentration. Aliment Pharmacol Ther 1992; 6: 103-11.

37 Kuo B, Castell DO. Omeprazole $20 \mathrm{mg}$ bid provides better acid suppression than a single dose of $40 \mathrm{mg}$. [Abstract]. Gastroenterology 1994; 106: A1034. 